\title{
The Constraints Of The Teachers In The Implementation Of 2013 Curriculum At Smp Negeri 1 Dullah, Maluku
}

\author{
Umar Rahaded, Hendro Widodo \\ Master of Education Management, Universitas Ahmad Dahlan \\ E-mail address:1umrahaded8@gmail.com,2hwpgsd1960@gmail.com
}

\begin{abstract}
This study was aimed to describe the constraints of the teachers in the implementation of the 2013 curriculum. This study was descriptive research. The subjects were teachers in SMP Negeri 1 Dullah. The data were analyzed using the descriptive analysis technique. The data were collected using interviews, observation and documentation. The validity of the data was obtained through the triangulation method. The results of the study show that the constraints experienced by the teacher include making learning media, understanding teachers, integrating inter-learning lessons in thematic learning, and mastering information technology. While other constraints originating from the government including the distribution of books, assessment, teacher administration, time allocation, socialization, guidelines for implementing the curriculum, and learning activities in student books.
\end{abstract}

Keywords: Implementation constraint, implementation curriculum 2013.

\section{INTRODUCTION}

Education is one of the aspects that influences the progress of the nation to improve the quality of human resources. It is because education has a significant role and even remains as a major institution in the preparation of human resources (Wagiran, 2007). Various research and analysis show that science and technology and also the quality of human resources are the key factors in determining the competitiveness of a nation (Wen, 2003).

Indonesia has experienced changes of curriculum in several times. These changes are closely related to how important and strategic the role of curriculum in the implementation of national teaching system (Soerdijarto, 2004). In line with this statement, Sukmadinata (2013) states that the curriculum is an absolute requirement which means an inseparable part of education and teaching.

Based on the Law of Republic of Indonesia, Number 20 year 2003 concerning about the National Education System states that curriculum as a set of plan and arrangements regarding the objectives, content, and learning materials as well as the ways it is used as guidelines for organizing learning activities to achieve certain educational goals. In line with this, Fujiawati (2016) emphasizes that curriculum and learning are an integral part of the national education system.

The curriculum concept includes a substance which is perceived as a learning plan for students or a set of goals to be achieved. Furthermore, it is explained by Gunawan (2011) that the education curriculum has the obligation to develop human potential maximally throughout their physical and spiritual. Saylor and Alexander states that the curriculum does not only concern about the subjects that must be learned but it involves all the school's efforts to influence the students' learning process both inside and outside the classroom even outside the school where these activities are under the responsibility of the teacher (Saud, 2011). The essence of 2013 curriculum is in the effort of simplification, and thematicintegrative. 2013 curriculum is prepared to produce generation that is ready to face the future, therefore the curriculum is prepared to anticipate the future developments (Muhammedi, 2016).

Based on the observation of the researcher, it is clear that during this time the responsibility of the local government (Tual City) seems to be limited 
to how to recruit teachers to take care of teachers' welfare or certification. In fact, there are things far more important than all of this, such as how to maintain and guarantee the quality of teachers in the regions to remote areas. While the duty of the central government is to be responsible for teacher certification, ensuring the availability of teachers, and designing teachers' needs. In line with the spirit of decentralization of education, the duties and responsibilities of regional governments including ensuring the quality of teachers in the regions, in this case are required to conduct training, socialization both formally and informally.

Although at the provincial level there is a special institution who guarantees that quality, called LPMP (Educational Quality Assurance Agency), however, in the regions even in remote areas, the supervisory function is not optimal in each school year. There is only hope for the UPTD (regional task implementation unit) of the education office in the sub-district. Nevertheless, whether those who are placed at UPTD are those whose professions and competencies are in accordance with what is needed by the teachers, especially education quality assurance is still unsure. Since what is important from any curriculum implementation is the form of changes which lies in the quality of the learning process and consistent supervision.

The initial identified obstacle since the beginning of the implementation of the curriculum up to three years running at SMP Negeri 1 Dullah is how the teachers have not been able to adapt well in the implementation of 2013 curriculum from all aspects ranging from aspects of administration to teaching and learning activities in the classroom. The socialization and training held by the government have not been optimal according to several informants at the school. It is caused by some teachers who cannot do well in the learning process including the curriculum development which is also not optimal in SMP Negeri 1 Dullah these day. Refer to the latest KBK curriculum which is developed into KTSP (educational unit level curriculum) since 2006 and applied in various schools until now, besides arranging proper lesson plan, the way the teachers deliver teaching materials in front of the class is not much different from year before the establishment of KBK (competency- based curriculum) or KTSP. The teacher's performance is still monotonous which can be labeled as teacher-center or explanation based on textbooks where the students only become passive spectators without any interaction that enlivens the classroom atmosphere.

\section{METHOD}

\section{Research design}

This research is a qualitative descriptive study with case study research design. In this study, the researcher is the key of data collection instruments. Stages of data collection including interviews, observation, and documentation. This research was conducted on $26^{\text {th }}$ May 2019 until $18^{\text {th }}$ July 2019 at SMP Negeri 1 Dullah, Tual, Maluku. The main data source in this study is the Mr. / Mrs. Teachers of SMPN 1 Dullah who have the mandate to carry out teaching and learning activities to the students of class $\mathrm{X}$ and class XI who have used the 2013 curriculum. The stages of data analysis in this study are: (1) collecting data; (2) reducing data; (3) categorizing data into each research focus; and (4) summarizing data. Checking the validity of the data through research persistence, re-observation, source triangulation and data triangulation.

\section{RESULTS AND DISCUSSION}

\section{Results}

Based on the results of the interviews and direct observation conducted by the researcher to the respondents showed that the constraints faced by teachers at SMP Negeri 1 Dullah can be classified into two categories. First, the constraints that come from the government or related agencies. Second, the constraints that come from the teacher itself.

Based on two classifications of constraints source, the first constraint originating from the government can be detailed as follows: (a) Constraint includes the distribution of books which are unequal and often not timely. As the result of the late distribution of books in recent years, SMP Negeri 1 Dullah still uses the 2016 books in teaching and learning process. Teachers get relevant materials by downloading on the internet, so this certainly has an impact on teaching and learning activities that are less than optimal. (b) Assessment 
in 2013 curriculum (assessment guidelines are unclear, report cards format is difficult and types of thematic tests that do not have guidelines). The number of themes and sub-themes must be assessed one by one. However, points on the assessment are excessive, so that it causes more time-consuming for teachers in sorting out the four aspects that will be assessed directly during teaching and learning activities. The assessment items are too complicated in each sub-theme and themes, for example in the aspect of attitude assessment in which the teachers find it difficult because of the large number of students that cannot be monitored one by one during the teaching and learning activities. The assessment is instructed from starting the class to the end of learning. (c) Teacher administration are excessive and complicated. The delay of the distribution of syllabus which is compiled and distributed by the central government so that teachers must find solutions to solve this problem by adjusting the new syllabus with the lesson plan that will be used for teaching. (d) Allocation of time (the duration on the teacher's book and student's book is not balanced, the materials do not match with the time allocation). The order of the materials compiled by the government is not in accordance with the logical sequence of both the book and syllabus, so teachers are required to be able to modify and adjust the material to be more relevant with the logical sequence and the allocation of time and understanding of students. (e) The socialization of 2013 curriculum which is not massive and balance. The socialization of the implementation of the K13 curriculum has not been optimal. The socialization activities that should be the main key in providing understanding for teachers in the implementation of 2013 curriculum have not been held massively and thoroughly, not all teachers have obtained socialization. (f) Curriculum implementation guidelines are unclear. Guidelines for the implementation of curriculum that are not wellunderstood by the teachers in SMP Negeri 1 Dullah. Teachers are still difficult to adapt to the existing guidelines because it is too complicated compared to the previous curriculum which is easy to understand and implement. (g) Learning activities in students' books that are supposed to be contextual are very textual.
The two constraints that come from the teacher include: (a) Difficulties in preparing learning media. Adjustments between books, syllabus and lesson plan make it difficult for teachers to prepare the ideal learning media. (b) The teacher's understanding of 2013 curriculum is relatively incomplete. Teachers who are not involved in the curriculum development process cannot adapt well to adjust the curriculum content, so that in its implementation most teachers are still confused in understanding the content and instructions for implementation. (c) Integrate content and then teach it in a thematic theme. In its implementation, most teachers still have difficulty in integrating several subjects in one theme. (d) Teachers' IT mastery is not optimal. IT mastery is a common problem in the Maluku region, especially in the city of Tual. This happened because of the very slow development of technology and of course inadequate infrastructure support, so that most teachers in schools have not mastered IT optimally. The trainings which are expected to develop mastery of IT have not yet been held massively and optimally by the government or related agencies.

\section{Discussion}

The 2013 curriculum which has been implemented for several years has various problems. However, these problems have actually been sought solutions from various parties. One of the determinants of the successful implementation of 2013 curriculum is the readiness and capability of the teachers. The readiness of the teachers in implementing the 2013 curriculum can be seen from the teacher's perception of the constraints and support for the application, while the teacher's capability can be seen from the teacher's competence and teacher's creativity in developing the curriculum.

According to Syaodih in Rusman (2009) to implement a curriculum based on design, it takes some preparations, especially the readiness of the implementers. No matter how good the design and curriculum design is, its success is depend on the teacher. Even a simple curriculum, if the teacher has the ability, enthusiasm, and high dedication, the results will be better than a great curriculum design. The implementation of the 2013 curriculum is a learning process consisting of (five $\mathrm{M}$ or five 
experiences). The main learning is observing, asking, and gathering information, associating, communicating (Trisnawati, 2016).

According to Kotler (2012), perception is the process of how a person selects, organizes and interprets information inputs to create meaningful overall picture. In this case, perception includes interpretation of objects, acceptance of stimulus (input), organizing stimulus, and interpretation of stimulus that have been organized by influencing behavior and forming attitudes. Therefore, perceptions of things can affect attitudes as well as behavior. Teachers' perception of the implementation of 2013 curriculum is a reflection of the readiness of teachers to welcome in implementing 2013 curriculum.

The results show that the application of 2013 curriculum comes from the government and teachers. This would be in accordance with the opinion of Mars in (Rusman, 2009) that there are several factors that influence the implementation of the curriculum, namely: support from agencies and principals, support from peer teacher, support from students and parents, and support from within the teacher are the main elements. When the elements above face obstacles, it is assured that it will hamper the process of implementation of a curriculum.

\section{Constraints Originating from the Government and the Department of Education}

The first constraint is the late distribution of books, said the respondents. This illustrates the process of distributing teachers' books and students' books in public and private junior high schools in Tual which are not evenly distributed and often experience delays.

The learning process is hampered, the students must also be willing to answer questions on other papers not in books, because books are scarce. Another constraint is of course teachers and students still use manuals in 2016 due to the distribution of books that have not yet arrived, even in previous years, books have also not been distributed to schools. Rusman (2009) suggests that the main types of learning resources are learning resources that are created or learning resources by design that is specifically designed or developed as "instructional system components" to provide direct and formal learning facilities. Teacher's books and student's books are instructional sources designed by the government in implementing 2013 Curriculum. If the teacher and student' books have problems with distribution, learning process will certainly be disrupted because teacher and student's books are specifically designed sources for the implementation of 2013 Curriculum.

The second constraint of the implementation is technical assessment. The assessment process also filling of the students' report cards are still confusing. This illustrates if the assessment is a crucial problem faced by teachers in the implementation of 2013 curriculum. There are several constraints in the assessment, such as; first, at the planning stage, there are many teachers in the field who have not yet understood about: the questions guidelines and its uses, also analyzing the assessment instruments and make scoring guidelines or questions rubric about the description. Second, at the implementation stage, it was found that many teachers have difficulties in carrying out assessments in 2013 Curriculum, especially difficulties in attitude assessment, and thematic learning assessments, as well as difficulties in analyzing assessment instruments (Setiadi, 2016).

Based on the Minister of Education and Culture Regulation Number 66 year 2013 about Assessment Standards which mentions the assessment of education as a process of gathering and processing information to measure the achievement of students' learning outcomes including: authentic assessment, self-assessment, portfolio-based assessment, tests, daily tests, midterm tests, tests end of the semester, competency level exams, competency level quality exams, national exams, and school / madrasah exams. The expectation from the government regarding the assessment is very good, for example the child is assessed authentically, leaving the subjectivity of the teacher. Assessment in 2013 curriculum is something new that teachers need more time to be able to adjust and process students' learning outcomes to be grades. In addition to being new, the assessment guidelines provided by the government is lack of explanation in detail and the application.

The third constraint of the implementation is related to teacher administration. The problem of 
many teachers administrative burden has become a polemic since the past KTSP (Education Unit Level Curriculum), with the enactment of 2013 Curriculum, it is expected that teacher administrative burden will decrease. In fact, the administrative burden on teachers is still excessive and burdensome.

Talking about the duty of teachers in 2013 curriculum in concept is actually not much different from the curriculum in KTSP that has been running so far. Teacher's standard competency still refer to four competencies regulated by Permendiknas Number 16 year 2007, namely professional competence, pedagogical competence, social competence and personality competence. Education Unit Level curriculum is considered to be more time-consuming for teachers in administrative matters, such as making syllabus and lesson plan and making portfolio of children. That is why to avoid administrative matters that take up a lot of teacher's time, in this 2013 curriculum the syllabus has been prepared by the central government so that the task of the teacher administratively is decreasing because all that remains is to prepare the lesson plan. However, in reality on the field, the syllabus promised by the government is late and the teacher is still struggling with the burdensome administration.

The fourth constraint relates to the unequal management of time on teacher's book and student's book (the material does not correspond to the time allocation) and errors in the teacher's book or student's book. The readiness of the government in compiling teacher's books and student's books is impressed in a hurry. Therefore, the active role of the teacher is needed in the learning process. The existence of material that is not in accordance with the existing concept must be addressed with the correction of the concept so that misconceptions will not occur in students. The order of the material does not have to match with what is in the Student's book, Teacher's book, or syllabus. The teacher must order the material in logical order. The teacher has full power to change or modify the material in the book or syllabus as long as it is in accordance with true academic logic. For any differences, errors, or lack of time allocation, the teacher must adjust to the level of student understanding.
The fifth constraint relates to the unbalanced time management of the teacher and student's books (the material is not in accordance with the time allocation) and errors in teacher and student books. The readiness of the government in compiling teacher books and student books is impressed in a hurry. Therefore, the active role of the teacher is needed in the learning process. The existence of material that is not in accordance with the existing concept must be addressed with the correction of the concept so that misconceptions will not occur in students.

The order of the material does not have to match with what is in the Student's Book, Teacher's Book, or syllabus. The teacher must order the material in the logical order of the material. The teacher has full power to change or modify the material in the book or syllabus as long as it is in accordance with true academic logic. For differences, errors, or lack of time allocation, the teacher must adjust to the level of student understanding.

The sixth constraint relates to 2013 curriculum socialization. Curriculum socialization is considered to be unequal in all Public and Private Junior High Schools in Tual. Ningrum (2015) emphasizes that socialization in implementing curriculum is very important, so that all parties involved in implementing the curriculum in the field of understanding the changes that must be made in accordance with their main tasks and functions, so that they provide support for curriculum changes.

Facts in the field show that not all teachers have obtained information, while 2013 Curriculum has been implemented for one year. The local government and related agencies need to rearrange the dissemination of information. If the socialization has not been obtained by the teachers as a whole, then how about learning process using 2013 curriculum that has been going on so far. Another constraint related to socialization is the quality of instructors in the socialization.

Several things were revealed in the respondents' response stating that training methods were dominated by one-way lecturing. A national instructor recruitment system was selected from the best and most outstanding teachers. But in reality, 
the government's hopes that they can provide an understanding to the targeted teacher has not been accomplished perfectly. The teacher training process must be improved because it affects the quality of teaching that will be given to students.

The last constraints are the obstacle for curriculum implementation guidelines which are not clearly revealed by the respondents and the obstacle of students' textbook that are supposed to be contextual are actually very textual.

Contextual learning is a learning model that develops knowledge, thinking abilities and skills by using students' knowledge through direct interaction with learning resources designed in the syllabus and lesson plan. In direct learning, students conduct activities to observe, ask questions, gather information, associate, and communicate. Direct learning produces knowledge and direct skills which is called instructional effect learning effect (Zainuddin, 2015).

\section{Constraints Originating from the Teacher}

The success of 2013 curriculum is not solely the responsibility of teachers as the implementers in the field. The role of the teacher is important, however the role of the teacher in implementing the curriculum will be optimal with the support of schools and government (Melati, 2016).

Rusman (2009) argues that educational resources such as infrastructure, costs, organization, and environment are the keys to educational success, but the main key is the teacher. The teacher is an important factor in the implementation of the curriculum. However, ideally a curriculum without the support of the teacher's ability to implement will not be meaningful as an educational tool (Sanjaya, 2010).

Thus, teacher's role in implementing the curriculum is a key position. Therefore, in the 2013 curriculum, teacher is the "main figure" in implementing the curriculum that must be thoroughly prepared. All teachers must be empowered and required to understand the substances of the curriculum and its application in the learning process.

The key to the success of an education lies in the quality of the teacher and the professionalism of the teacher, although now technology is sophisticated and has become an inseparable part in the world of education. Teachers must not change their function as transformers of knowledge for students who guide their students in the process of finding the truth based on science because a teacher is an example for their students in character and performance. It was also stated by Wijayanti (2016) that difficulties are experienced due to the lack of guidelines for integrating and consolidating materials between several subjects or scientific studies in one theme.

Based on respondents' statements relating to the constraints of teachers' difficulties in preparing learning media, according to Sanjaya (2010), it is suggested that teachers have a role as adapters, more than just implementing the curriculum, but also aligning the curriculum with the characteristics and students' need. Learning media is the result of teacher's creativity to align students' need and curriculum demands. The correlation between learning media with the objectives, materials, methods, and conditions of the learner should be a concern and consideration of teachers to choose and use media in the learning process in class so that the media used is more effective and efficient to achieve learning objectives. Learning media is one of the important aspects in learning process using 2013 curriculum.

A teacher needs to have the ability to design and implement a variety of learning strategies that are considered suitable with the interests and talent and also the level of development of students including utilizing various sources and learning media (Sanjaya, 2010). Furthermore, according to Kosasih (2014) the role of teacher in studentcentered learning shifted from the original instructor to be the facilitator. Teacher as facilitator must have an understanding of students through teaching and learning activities, in addition, teaching and learning outcomes will be optimal if students are welldirected and given appropriate and intense motivation (Mulyasa, 2013).

Other constraints relate to teachers' lack of understanding of 2013 curriculum. Basically, the teacher has the role as curriculum developer, thus the teacher has the authority to design a curriculum. Teacher not only be able to determine the objectives 
and learning content, but also to determine what strategies must be developed (Sanjaya, 2010).

The results of interviews with school principals and teachers indicate that teachers were not yet involved in the curriculum development process, making teachers unfamiliar and confused. This confusion is perceived by almost all education practitioners in Indonesia. The government has not been consistent with the issue of frequently changing the Permendikbud. Additionally, Permendikbud that changes in a short period of time indicates the lack of readiness of the government and related agencies in implementing 2013 Curriculum. It is proved by the many errors, deficiencies, and contradictions between one Ministry of Education and Culture and another Ministry of Education. This is also an indicator of a strong desire for the implementation of the curriculum without being based on scientific studies on the feasibility of its application.

Constraints come from teacher's competence, especially in terms of thematic: combining content and teaching in certain theme is still considered difficult for some teachers. Thematic learning is one integrated learning model that uses themes to connect several subjects to provide meaningful experiences for students. Integrated learning is defined as learning that connects various ideas, concepts, skills, attitudes, and values, both between subjects and in one subject. Thematic learning emphasizes the selection of a specific theme that is appropriate to the subject matter, to teach one or several concepts that combine various information. The problem is in the practice where a number of teachers still have difficulty coordinating several of these subjects in one theme.

As a result, teacher seems to teach kind of collection of subjects yet present it alternately. In essence, thematic learning is an implementation of an integrated curriculum. For example, a classroom teacher lacks of depth elaboration of themes, so that in thematic learning it will be difficult to associate the theme with the subject matter of each subject. In addition, if the learning scenario does not use innovative methods, the achievement of standard competency and basic competencies will not be achieved because it will become a worthless narrative without meaning. In addition, it was also revealed how difficult it was for teachers to understand the learning models offered in 2013 Curriculum.

The last constraint is related to teacher competency is IT mastery. Although it is only disclosed by the respondents, from year to year mastery of IT becomes homework for teacher competencies in Indonesia.

In order to implement 2013 Curriculum. Katuuk (2014) suggests that there are several important aspects of management as a strategy to strengthen their implementation. These aspects include things like implementation planning, main and supporting resources, learning activities in schools, as well as monitoring and evaluation activities. On the other hand, the school component consists of teachers, principals, facilities, culture, and environment.

\section{CONCLUSION}

The obstacles experienced by the teachers of SMP Negeri 1 Dullah in the implementation of 2013 curriculum come from the government and the teachers. Constraints from the government include the distribution of books, assessments, teacher administration, time management, socialization, thematic learning implementation, curriculum implementation guidelines, and learning activities in student's books, while constraints from the teachers include the creation of instructional media, teacher understanding, integration of learning content in learning thematic, and mastery of information technology.

Related to the existing constraints, it is recommended to the government in this case the Ministry of Education and Culture to conduct an evaluation of the implementation of the curriculum covering all aspects to achieve advancement in overall implementation in all regions of the Unitary State of the Republic of Indonesia, to the local government (Department of Education and Culture of Tual) to organize massive socialization and training in order to increase theoretical and practical understanding of the curriculum in all junior high schools or equivalent in the Tual area in order to improve the quality of teaching and learning in schools. Suggestions for the teachers to be able to optimize forum meetings between subject teachers 
(MGMP) to learn and understand the curriculum thoroughly both theoretically and practically.

\section{REFERENCES}

Fujiawati, F. S. (2016). Pemahaman Konsep Kurikulum dan Pembelajaran Dengan Peta Konsep Bagi Masiswa Pendidikan Seni. Jurnal Pendidikan dan Kajian Seni, Vol. 1, No. 1, 2503-4626.

Gunawan. (2011). Merekonstruksi Fitrah Pendidikan. Komunikasi. Malang: Majalah Kampus Universitas Negeri Malang.

Katuuk, A. D. (2014). Manajemen Implementasi Kurikulum: Strategi Penguatan Implementasi Kurikulum 2013. Cakrawala Pendidikan, No XXXIII. Manado: Universitas Negeri Manado, $1-11$.

Katuuk, D. A. (2014). Manajemen Implementasi Kurikulum: Strategi Penguatan Implementasi Kurikulum 2013. Cakrawala Pendidikan, No XXXIII. Manado: Universitas Negeri Manado, $1-11$.

Kosasih. (2014). Strategi Belajar dan Pembelajaran Implementasi Kurikulum. Bandung: Yrama Widya.

Kotler, P. (2012). Marketing Management Edisi Milenium, International Edition. New Jersey: Prentice Hall. International, Inc.

Melati, E. R. (2016). Kendala Guru Sekolah Dasar dalam Memahami Kurikulum 2013. Indonesian Journal of Curiculum and Educational Tecnology Studies, Vol. 4, No. 1, 1-9.

Muhammedi. (2016). Perubahan Kurikulum di Indonesia Studi Kritis tentang Upaya Menemukan Kurikulum Pendidikan Islam yang Ideal. Raudah, Vol. IV, No 1, 49-70.

Mulyasa, E. (2013). Standar Kompetensi dan Sertifikasi Guru. Bandung: Remaja Rosadakarya.

Ningrum, S. (2015). Implementasi Kurikulum 2013 di Sekolah Dasar. Jurnal Manajemen Pendidikan, Vol. 24, No. 5, 416-423.

Permendiknas Nomor 16. (2007). Standar Kualifikasi Kompetensi Guru. Jakarta: Sekertariat Negara Republik Indonesia.

Rusman. (2009). Manajemen Kurikulum. Jakarta: PT Raja Grafindo Persada.
Sanjaya, W. (2010). Kurikulum dan Pembelajaran. Jakarta: Kencana.

Saud, U. (2011). Pengembangan Profesi Guru. Bandung: Alfabeta.

Saud, U. (2011). Pengembangan Profesi Guru. Bandung: Alfabeta.

Setiadi, H. (2016). Pelaksanaan Penilaian Pada Kurikulum 2013. Jurnal Penelitian dan Evaluasi Pendidikan, Vol. 20, No. 2, 166-178.

Soerdijarto. (2004). Evaluasi Hasil Belajar. Surakarta: Pustaka Pelajar.

Sukmadinata, N. S. (2013). Metode Penelitian Pendidikan. Bandung: PT Remaja Rosdakarya.

Trisnawati. (2016). Perbandingan Implementasi Kurikulum Tingkat Satuan Pendidikan (KTSP) dan Kurikulum 2013 di SMAN 1 Sinjai Utara. Jurnal Mirai Management, Vol. 1, No. 1.

Undang-undang Republik Indonesia, Nomor 20. (2003). Sistem Pendidikan Nasional. Jakarta: Departemen Pendidikan Nasional.

Wagiran. (2007). Determinan Keberhasilan Penerapan Inovasi Kebijakan Pendidikan (Studi Penerapan Kurikulum SMK/KTSP). Yogyakarta: Universitas Negeri Yogyakarta.

Wen. (2003). Future of Education. Batam: Lucky Publishers.

Wijayanti, E. C. (2016). Kesulitan-kesulitan Dalam Implementasi Kurikulum Mata Pelajaran IPS SMP. Jurnal Pendidikan, Vol. 1, No. 11, 22412247.

Zainuddin. (2015). Implementasi Kurikulum 2013 Dalam Membentuk Karakter Anak Bangsa. Jurnal Keislaman dan Kebudayaan Vol. 9, No. 1, 19756948. 